\title{
Agriculture in the Northwest-European Delta Metropolis
}

\author{
P.J.A.M. Smeets ${ }^{\#}$
}

\begin{abstract}
The southern and central regions of The Netherlands are part of the NorthwestEuropean Delta Metropolis. The demands placed by modern, urban society on the agricultural sector are numerous. Not only are the environment, animal welfare, and food hygiene and quality at stake here, but also must these demands be met in a period of a structural decline in economic yields and under the permanent pressure of a shortage of available land. Intensification and increase of scale, which have characterized European agriculture for a long time, are set to continue in the future. As a direct consequence of these developments five perspectives can be described that together have considerable implications for spatial planning in the rural areas. These perspectives are:

(1) The development of knowledge for the benefit of the agro-food sector.

(2) The development of agro-production parks based on the principles of industrial ecology.

(3) Large-scale, intensive, heavily specialized land-based agriculture.

(4) 'Dreams and folk stories' that either relate to traditional production methods or are the product of modern marketing.

(5) Specialized management of nature and landscape.

The pressure on the agrarian cultural landscape, for centuries a by-product of traditional agriculture, is rapidly increasing as a result of these developments. In this paper it is argued that the problems of the future of the landscape in Northwestern Europe should be tackled outside the traditional framework of the agrarian production.
\end{abstract}

Keywords: Delta Metropolis; urbanization; agriculture; agro-industry

\section{Delta Metropolis: centre of global competition}

\section{Delta-metropolitan areas in the world}

The great metropolitan areas are the centres in which the 21 st-century global competition is taking place: "The coming decades will see an increase in global urbanization with most of the increase taking place in low-income countries which contain in 1995 nearly 60 percent of the world's population. Many of these countries have large metropolitan areas whose populations will continue to grow as urbanization increases" (Ingram 1997).

Throughout history metropolitan areas have developed near centres of government but in China and Europe another type of metropolis can be distinguished:

\footnotetext{
\# Alterra Green World Research, Landscape Centre, PO Box 47, 6700 AA Wageningen, The Netherlands. E-mail: peter.smeets@wur.nl
} 
the Delta Metropolis (Figure 1). The emergence of Delta Metropolises on the Eurasian and African continents has been concentrated mainly in China and Europe, where great rivers have formed the major transport arteries since time immemorial. This way these societies could transport large loads on the rivers and as a result the larger cities developed in the late Middle Ages around the transit ports. In the rest of the Old World the camel was still the main mode of transport and loads of around 150 kilograms were transhipped in the caravanserais, which then developed into small trading centres at intersections on the caravan routes. Where even the camel could not pass people (mainly women) carried small loads from village to village and transhipment locations had no relevance whatsoever.

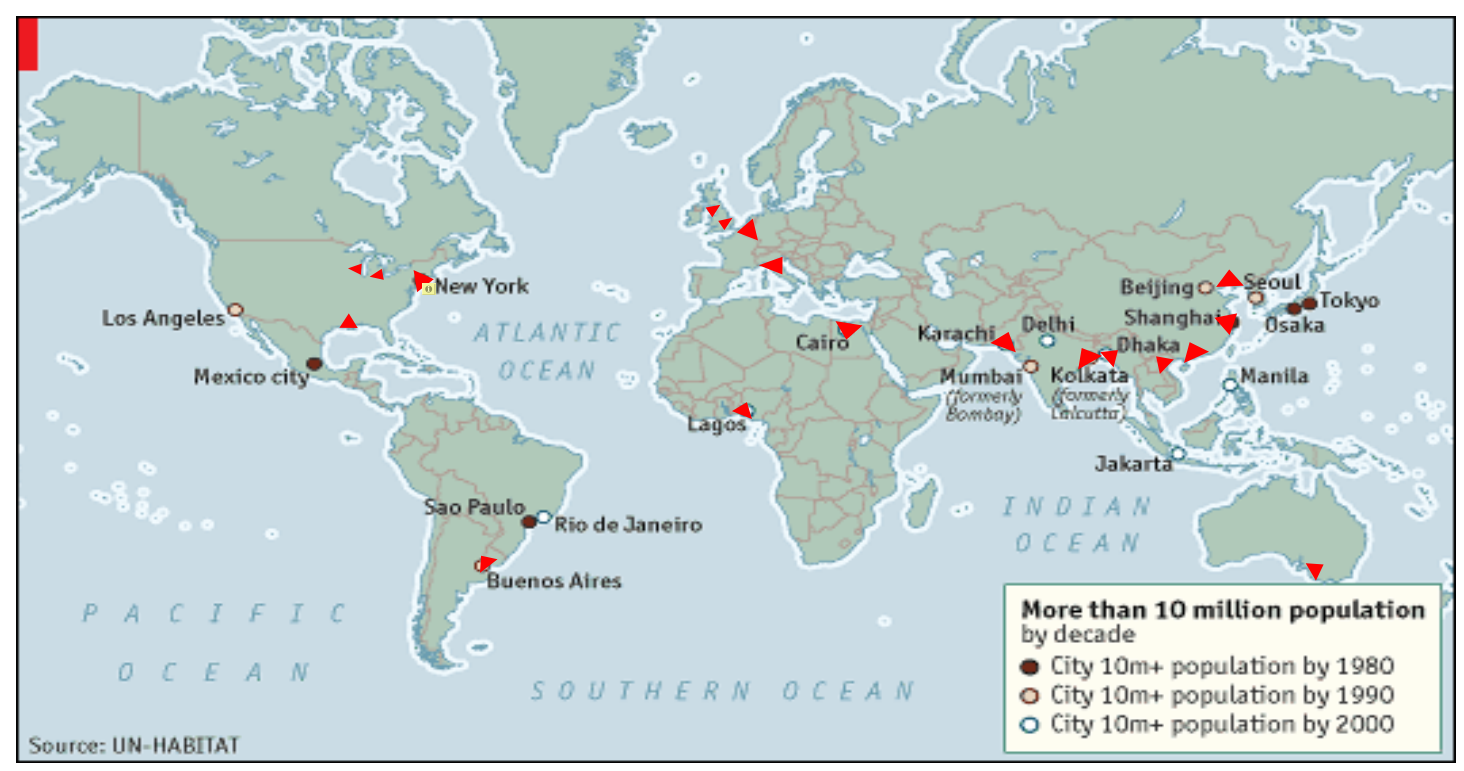

Figure 1. World mega-cities: Metropolises and delta-metropolitan areas of the world (triangles)

In China and Europe, however, the transit ports became the metropolises, which were in contact with the rest of the world and often developed separately from the administrative centres founded by the rulers at other locations: in The Netherlands Amsterdam and Rotterdam developed alongside The Hague, in Belgium Antwerp and Bruges alongside Brussels, and in China Wuhan alongside Beijing. An exception to the rule was Turkey with Byzantium/Constantinople/Istanbul until Ankara was founded early last century. On the American continent the European model of metropolis development was copied following the colonization of the Dutch, the French and the British (McNeill 1987).

\section{The Northwest-European Delta Metropolis}

A survey on cities by The Economist (Turn up the lights, a survey of cities 1995) concluded with an intriguing question: “...Taking an even longer view, the growth of cities in increasingly integrated markets raises another intriguing possibility. In the United States, cities follow the so-called 'rank-size' rule. The largest city, New York, is twice the size of the two next biggest (Los Angeles and Chicago), which in turn are twice as large as those at the next level (...). And it can be remarkably precise. America's tenth largest city is Houston with $3.5 \mathrm{~m}$ people. The 100th largest is Shreveport, with 380,000. Now suppose the European economy becomes as integrated as that of the United States; might that cause a European New York to emerge, twice as large as any other European city?..." (Turn up the lights, a survey of cities 1995). 
A more loosely organized federation of European states would, according to the suggestion in this survey, lead to the development of a European super-metropolis, a European New York.

If we look at the map of Europe purely from the point of view of population density then the possible location for this European New York is immediately evident. An enormous area can be identified where the population density is greater than 100 inhabitants per square kilometre: the triangle between Lille, Amsterdam and the Ruhr area with an extension southeastwards to Frankfurt (Europese Commissie 1995). This is the Northwest-European Delta Metropolis, a new, large, hybrid urban pattern of urban concentration areas, suburban zones and open spaces (Smeets 1998).

\section{Delta-metropolitan spatial planning}

The development of the network economy has resulted in a spatial pattern of urban agglomerations, major ports and mega-corridors, with regional dispersion in the intermediate areas, linked by a network of multimodal infrastructure corridors containing road, railway and water transport axes. These corridors or zones form the infra-landscapes in which the economy functions. Their development is virtually autonomous and a very demanding and dominant factor in the use of space. The demand for high-quality residential areas for those who work in a knowledge-

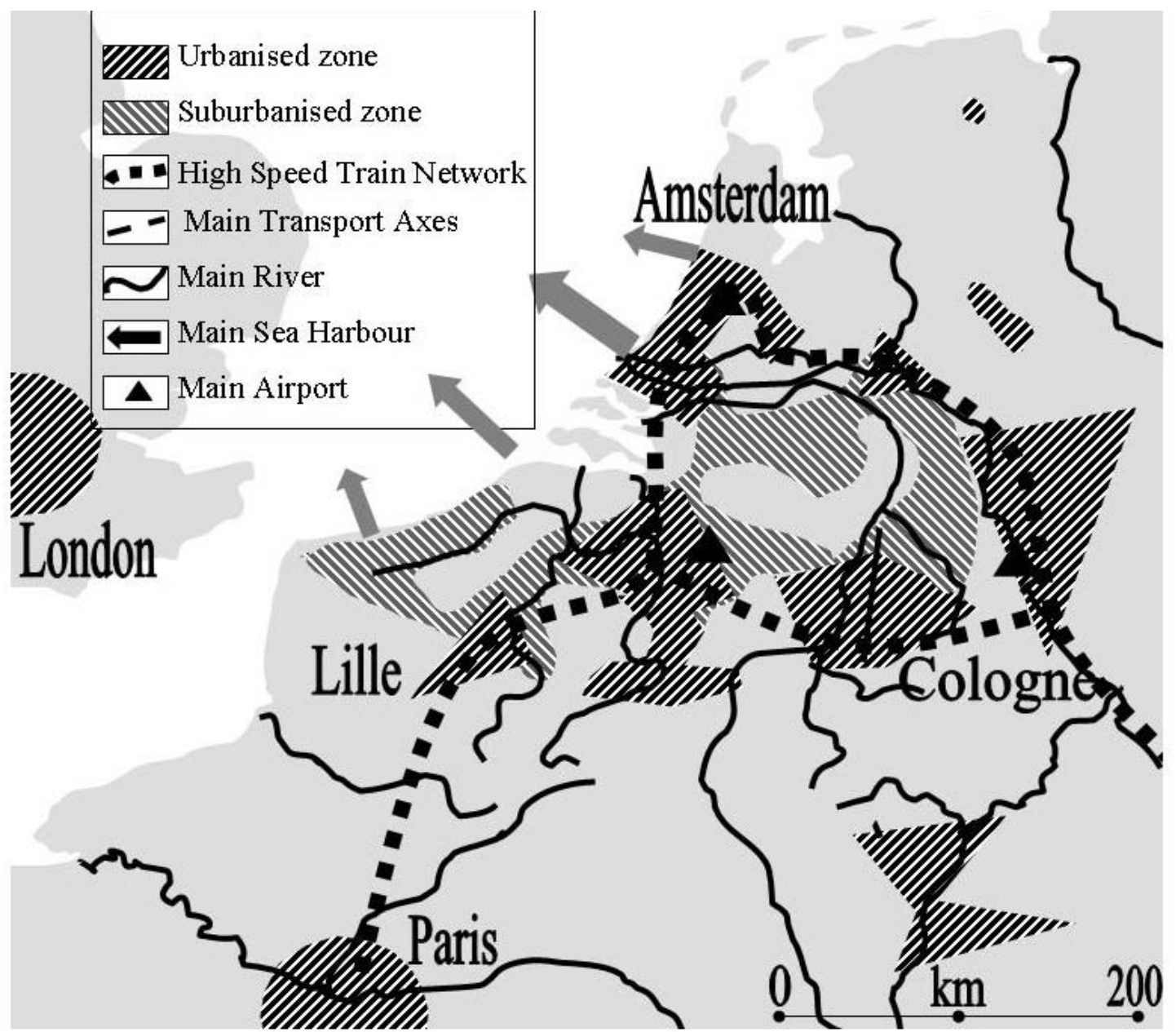

Figure 2. The Northwest-European Delta Metropolis as described in the Second Structure Plan for the Benelux (Tweede Benelux structuurschets = deuxième esquisse de structure Benelux 1996) and the Fifth Dutch National Policy Paper on Spatial Planning (Ministerie van Volkshuisvesting 2001) 
intensive and services-dominated society is becoming an important factor in decisions about investment options for economic activities.

It was in the Structure Plan for the Benelux Countries (Belgium, The Netherlands and Luxembourg) that the contours of the Northwest-European Delta Metropolis first took shape on a map. More recently the Fifth Dutch National Policy Document on Spatial Planning refers to a 'transnational Northwestern-European policy vision' (Figure 2).

Viewed from this Northwest-European perspective on the Delta Metropolis, The Netherlands can be divided into two parts. The central and southern parts of the country are part of the Northwest-European Delta Metropolis. Urban core areas (Randstad, Ruhr area), suburban zones (Brabant, Flemish Triangle), corridors (INCODelta) and green open spaces (Green Heart of the 'Randstad', Rhine-Scheldt delta) are interspersed with each other. The North of the country, on the other hand, is part of the Northwest-European lowlands. There, small and medium-sized cities are the motors of the economy and the proximity of the Delta Metropolis is driving up land prices.

\section{Agro-industry from self-supporting village communities to globally operating agrofood chains}

For a number of decades The Netherlands has played a prominent role in food production as far as productivity, environmental efficiency, food hygiene, social awareness and scientific knowledge are concerned. There is a common misunderstanding that this pioneering role is linked to the rural areas; in fact it is linked to the urban areas. Historical descriptions even refer to the agro-industrial complex as one of the fundamental pre-conditions of the origin of Dutch society. The American historian Wallerstein (1980) wrote about The Netherlands in the Golden Age as follows: ".... if it is to be asserted (...) that The Netherlands was the first country to achieve self-sustained growth, it is primarily because no other country showed such a coherent, cohesive and integrated agro-industrial production complex...". And this rock-solid combination between port-related metropolitan development and agro-industry has continued right up to the present day. The port metropolis in particular offers a cluster of location-related advantages:

- High levels of knowledge amongst entrepreneurs and management in the sector itself and amongst people and firms in the periphery (financial services, equipment, maintenance etc.).

- Good infrastructure and logistics.

- Instantly available markets in the form of many (critical) consumers.

- A large pool of cheap labour.

- A large supply of ancillary and by-products for waste processing and chain management.

- Possibilities for growth from monofunctional chains to network complexes.

In this way the development of the Northwest-European Delta Metropolis must not be seen as a threat but as an opportunity for the further qualitative and quantitative growth of the agro-industry.

Food production has developed over the past centuries from closed, selfsupporting village communities to globally operating agro-food chains and in this development has become more socially oriented. Food production takes a prominent place in these chains but around it the population, consumers, social organizations, banks, knowledge institutions and the public sector operate. The agro-food chains have radically altered their orientation in recent decades. The primary producers (the 
farmers) used to have the leading role but today the chains are demand-orientated and the supermarket plays the role of chief organizer, sometimes explicitly, sometimes in the background (e.g. with respect to pig farming).

Consumer demand is measured directly at the supermarket checkouts, but where longer-term issues are concerned social organizations represent the consumers and the population as a whole. While consumers and the population as a whole are one and the same, they speak, as far as the manager of the chain is concerned, with two voices. In surveys and via social organizations the population wants biological production and sets high environmental standards, but at the supermarket checkout consumers still often choose the mass-produced items.

Social consciousness has grown with the development of the chain. Whereas the farmers used to have precious little freedom as entrepreneurs (right to produce), these days the various parts of the chain must constantly strive to retain their licences to produce. With the increasingly more important role of the supermarkets the licence to deliver becomes more important.

A final myth that must be addressed is the 'Arcadian reference'. To a large extent, people over 40 years have happy memories of life on the farm. They seldom grew up on the farm - in which case they would hold a different view - but went there on holiday with the family. The memories from those holidays can still be recognized even today as images of an ideal agricultural sector. These images are recalled as a response to the crisis images of industrial production that we do not wish to see. And this way the 'Arcadian reference' arises: cows in the meadows, pigs in mud and the mixed farm. To many people the word environment was hardly known, so environmental problems would presumably solve themselves if this form of production were rejuvenated. Biological farming owes part of its attraction to the same reference and also a number of nature and landscape policies refer to agrarian cultural landscapes: meadow birds and heath lands. In these policies the modern farmer is still regarded self-evidently as the manager of these nature areas as a byproduct of the food production.

It is, however, apparent that agriculture no longer plays this role. The reference is no longer sustainable. And as the generations older than 40 years age they gradually disappear, and with them the relevance of the 'Arcadian reference' for agriculture and for nature and landscape policies.

\section{Dilemmas for spatial planning and agriculture}

The spatial planning of agricultural production in the future will partly depend on a number of choices made by various players in the social field.

Farmers are disappearing. This trend has been ongoing for centuries and will continue in the coming decades. An analysis by the Dutch Agricultural Economic Institute (Langelaan and De Bont 1999) of the developments between 1990 and 1998 shows that the motives are mainly related to personal circumstances - poor health, age, the absence of a successor - much more than the financial and economic position of the enterprise or the social orientation of the entrepreneur. This analysis also reveals that it is mainly the small and medium-sized enterprises that are diminishing in number. The larger enterprises are, on the other hand, growing in number.

The interests of the 'quitters' and 'stayers' are in many respects diametrically opposed to each other. High land prices offer possibilities of a comfortable pension but at the same time render a takeover of the enterprise virtually impossible. A farm that is transformed into a dwelling becomes, however, an object with a buffer zone of 
200 metres around it because of the nuisance caused by odour. Because of the number of both the 'quitters' and 'stayers' - too large to be ignored for their financial clout the respective interests are forced into positions where they adopt less extreme standpoints.

The dilemma that is the result of this mainly demographic trend also has spatial consequences. Some parts of The Netherlands appear to be more attractive than others for specific forms of primary production. This forces agriculture to take on the role of supplier of land. This position was predicted by the Netherlands Scientific Council for Government Policy (1992) in its report 'Ground for Choices'.

As argued above, the driving force behind the success of Dutch agriculture was mainly urbanization. The methods of modern agricultural enterprises are to a large extent industrialized. But the spatial organization has lagged behind this development, partly because of the earlier-mentioned lack of collaboration between the agricultural sector and spatial-planning interests in recent decades.

In reconstruction areas the development possibilities of intensive animal husbandry are restricted if they are located in the vicinity of nature areas or cause too much odour nuisance to nearby residential areas.

Agro-industry - the name gives it away - is industrial in nature and belongs on industrial estates. This agro-industry does not only include intensive animal husbandry and horticulture under glass but also fish farming and mushroom cultivation. Even dairy farming is developing into a footloose production sector, purchasing cattle feed from arable farms and food-concentrate producers and keeping cattle in stalls all year round.

In the most recent policy papers on spatial planning and agriculture this development is facilitated. In the most recent (fifth) Dutch National Policy Paper on Spatial Planning (Ministerie van Volkshuisvesting 2001) the dispersed development of horticulture under glass is no longer allowed and a limited number of locations have been designated as areas where this activity can develop in large clusters. The (second) Structure Plan for the Green Areas (Ministerie van Landbouw 2002) designates 13 possible areas for agribusiness parks and in so doing opens the door to this type of development.

\section{Food production as urban activity: the agro-(eco-)industry}

Together with its sister institutions IMAG and ATO, Alterra has played a pioneering role in recent years in the debate about the future agro-industry (De Wilt, Van Oosten and Sterrenberg 2000) with respect to research into design and planning, not the production of blueprints. An example of such a plan is the 'Californië' project location near Venlo. This plan proposes a distribution centre and concentrated location for horticulture under glass together with protein production. The concept maximizes consumer demands in the environmental, animal-health and welfare fields while striving for economic sustainability. A key element in this plan are the 8 to 10 multipurpose buildings shaped as pyramids in which agrarian entrepreneurs can hire production space and in which they take joint responsibility for environmental management, energy provision, water management and the logistical infrastructure. On the eastern, southern and western sides of the pyramids horticulture under glass is planned while the northern and inner areas provide space for protein production and cultivation under artificial light.

The protein production (pigs, poultry, eggs, fish, insects, fungi) in the pyramids is linked via an underground transport system to the central slaughterhouse that is also 
situated underground. The transport of surplus fertilizer also takes place underground to a central processing plant.

This industrial mixed enterprise works on industrial ecological principles (Figure 3). The vegetable and protein production exchange energy, carbon dioxide, minerals and waste products. Other parts of the chain can be combined with this cycle: feedstuff production, energy production, transport, logistics and processing. The resulting cluster can, in principle, be extended ad infinitum.

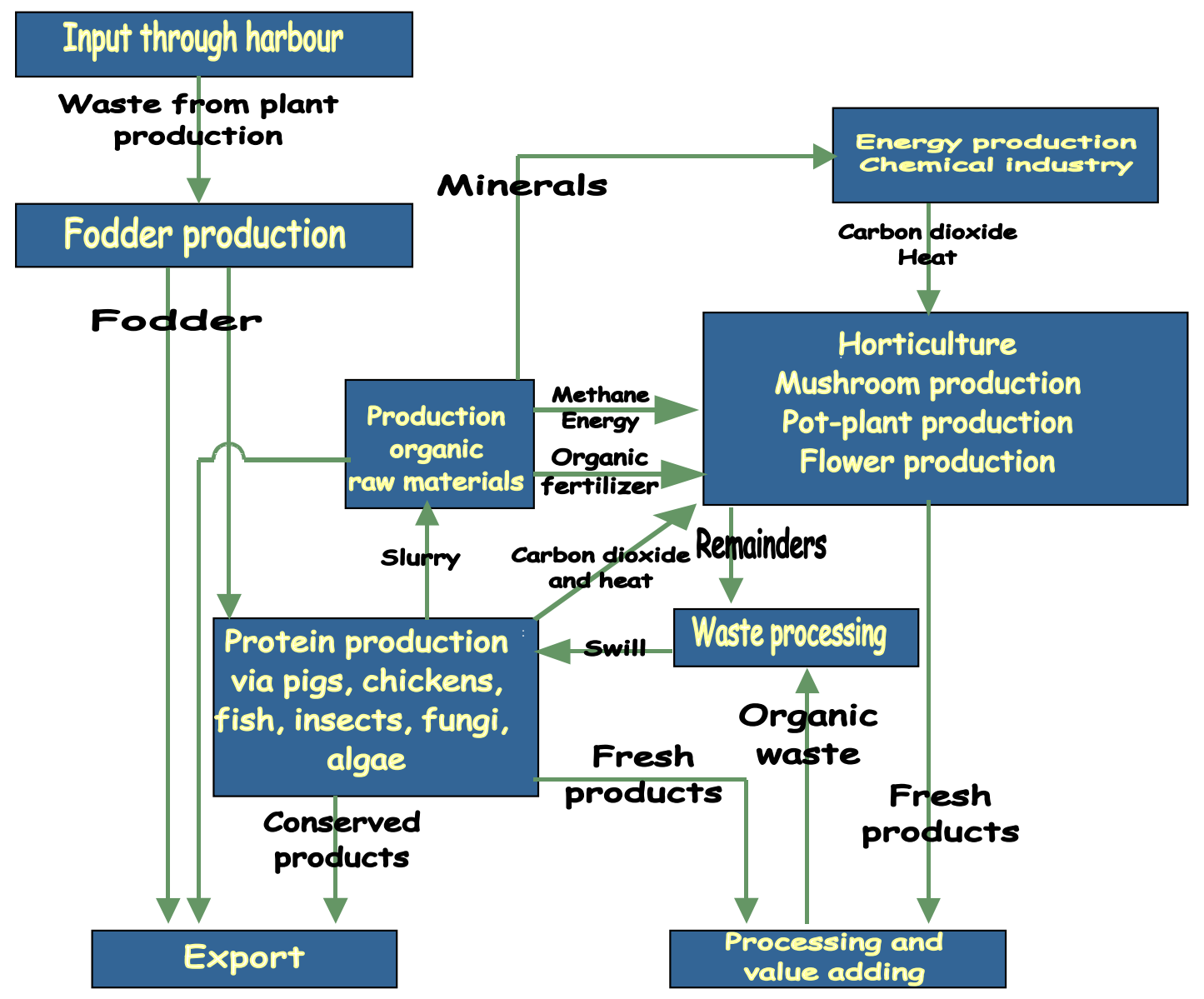

Figure 3. The application of industrial ecology in the agro-industry plan

The advantages and disadvantages of this plan have been debated widely in recent years in The Netherlands and elsewhere. These discussions concluded on the following strong and weak points:

Weak:

- High level of investment.

- Social acceptance.

- Competition for current enterprises.

Strong:

- Multiple land use.

- High standard of animal welfare (large land take-up and less animal transport).

- Reduction of transport and logistic problems.

- Reduction of risks of animal diseases by less transport and closed systems.

- Closed system for use of waste flows.

- Manageability of flows of minerals, energy and protein. 
- Manageability of production safety.

- Critical mass for sustainable, knowledge-intensive developments.

- Link to social preferences: animal- and environment-friendly.

\section{Food production in the rural areas: knowledge-intensive land-based agriculture}

Outside the city there are also perspectives for the development of land-based agriculture. However, it is no longer possible to develop anything anywhere, and in the Fifth Dutch National Policy Paper on Spatial Planning and the Second Structure Plan for Green Spaces we can see that the first tentative steps have been taken towards area-specific differentiation. Various push and pull factors can be distinguished that play a role in the future of land-based agriculture:

- The revival of land productivity. For decades the fertility of every square metre of land has been brought up to or above the desired standard that was deemed necessary for a particular type of production with the aid of artificial fertilizers and surplus organic fertilizer. During these decades the negative effects of this method were increasingly recognized and in recent years the resulting eutrophication of water, land and nature areas has led to legislation that, for some types of land, is so strict that the natural soil fertility once again is a relevant factor. Clay soils are evidently the most productive; these are the soils that, through their absorptive capacity, can cope best with the threat of over-fertilization. Dry sandy soils in particular have a great disadvantage in this respect.

- Water issues. In the higher parts of The Netherlands the quality and quantity of groundwater is threatened by over-fertilization and by crop spraying. In the river region the limits of technical applications used to counteract the rising high water levels of the rivers have been reached. Instead, spatial solutions are being sought, for instance river widening and inundation polders. Such spatial solutions are being sought also in the other lower parts of The Netherlands where rainwater surpluses have to be dealt with. In these areas there is an additional problem of increasing salinification as a result of the rising sea level and the fall in the level of the land. Peat-meadow areas and small areas of drained land in particular are suffering most as a consequence of these water problems.

- Increasing urbanization. This will not only use up tens of thousands of hectares of land in the coming years but also has two indirect effects. With their newly acquired richness, farmers who have sold their land for urban or infrastructure development look elsewhere for land and so force up land prices. Moreover, the urban dweller wants enough green space and in this context large-scale land purchases are carried out, which also keep prices high.

Taking these factors together, the strong position of the clay soils in the northern and central areas of the country as the preferred locations for land-based agriculture is apparent, provided that the water problems in these areas can be shifted to the adjacent peat-meadow areas (Figure 4). On the clay soils in the Southwest of the country urbanization and the absence of spatial solutions to the water problems will, in time, put a brake on this perspective. The sandy soils have important limitations, in terms of environmental space as well as water management, and will offer possibilities mainly for specific types of cultivation. The peat soils have very limited possibilities with respect to the development of highly productive land-based agriculture. 


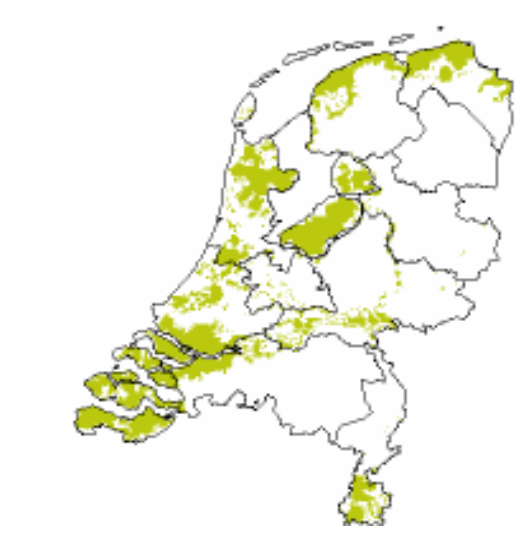

Soil fertility

stimulating on clay soils
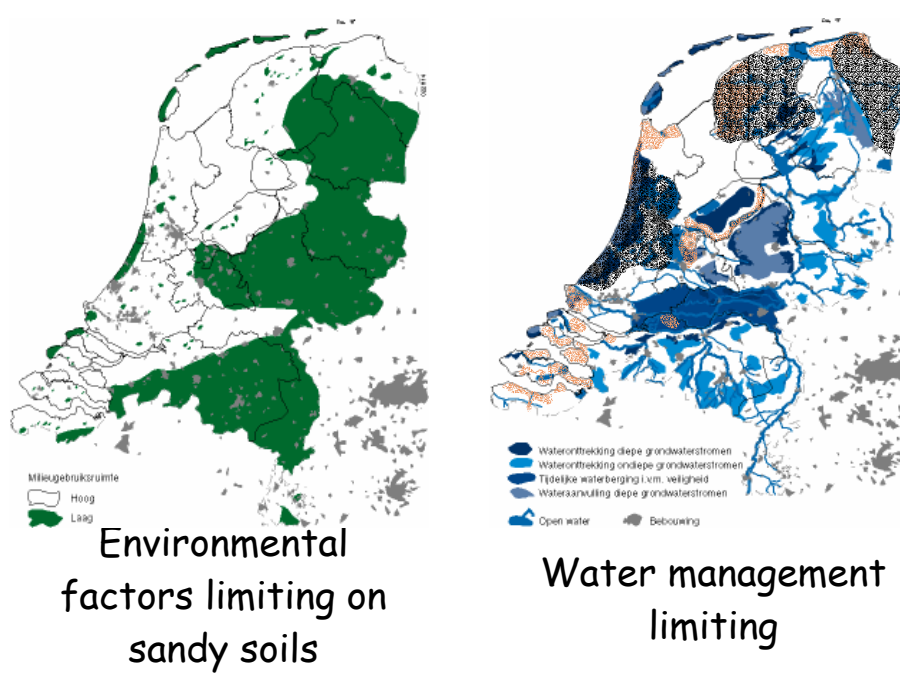

Figure 4. Dark areas: push and pull factors that influence the locational preferences for land-based agriculture

\section{Diversify agriculture or landscape?}

In many policy papers an important role is allocated to the diversification of agriculture. The idea is that farmers find a supplement to their income by providing all kinds of services that are in demand in the rural areas. These services can take many different forms: nature management, landscape management, recreation, care services, regional products, local produce sold on site etc. The 'Arcadian reference' is clearly recognizable in all these options. But there are also other options such as a second job completely separate from the running of the enterprise. The magazine of the Dutch Agrarian Youth Movement has even referred to brothels as a source of extra income (Hoeren tussen de boeren 2000). A number of beautifully illustrated books cover many of these possibilities (Van Broekhuizen et al. 1997).

The real world is, however, different. In The Netherlands no more than $9 \%$ of agricultural enterprises is actively involved in diversification, and the income that can be attributed to this comes chiefly from jobs that have nothing to do with the enterprise itself. Diversification seems to be a strategy mainly for entrepreneurs who see that in the end they will not survive the cut-throat competition in the foodproduction sector. But therein lies a paradox. Gambling on two or more entrepreneurial strategies seems to fly in the face of the demand for further specialization and professionalism that not only applies to food production but also to other sectors in which a diversification strategy is being pursued. Diversification is to all intents and purposes the beginning of the end of the agricultural enterprise. The enterprise will completely cease to exist or the entrepreneur changes tack and becomes a professional in the recreational sector, a cheese-maker or a manager and only retains a few token animals, continuing to live on the farm in order to pursue the dream of the 'Arcadian reference'.

This way the management of nature areas and the landscape is being put under pressure. No other aspect of government policy is so dependent on voluntary work, hobbies and second jobs. It cannot be reasonably expected of the agro-industrial food production in the metropolis or the heavily specialized, intensive, large-scale landbased types of agriculture in the rural areas that the management of nature areas or agrarian cultural landscapes be carried out as a by-product. If the diversification 
option is not a sustainable strategy then the management of nature areas and the landscape must be regarded as a problem, and the starting point for the solutions must be a combination with food production. New managers are sought for nature and landscape.

\section{Most desirable (policy) developments for The Netherlands and Europe}

Five sustainable perspectives can be distinguished from the above analysis of the relationship between agriculture and spatial planning. These perspectives co-exist at different scales. It is possible indeed to designate areas where a certain perspective is more appropriate than in others. These spatial perspectives are not, however, absolute.

\section{Agro-industry}

On the large industrial areas (existing and new) in and close to the cities that make up the Northwest-European Delta Metropolis, the perspectives for the agroindustry are good. Seaports and inland ports, linked to road and rail nodes, are very attractive spatial factors, together with the availability of residual heat. In the short term the relocated intensive animal husbandry enterprises will be, as part of a wholesale reconstruction, clustered on the industrial areas. In the medium term the most likely option is a combination of horticulture under glass with other types of vegetable and protein cultivation. In the medium and long term genetic modification and the development of functional foods will be integrated with each other.

\section{Intensive land-based high-quality production}

Agriculture on clay soils is already developing in the direction of large-scale, intensive mixed farms or complexes containing both dairy and arable farming. Cash crops - (root) potatoes and beet - are the most important, but environmental regulations require much more rotation than has been necessary so far, and in this system mainly basic feedstuffs (maize, grain, beet) are produced to serve the animalhusbandry enterprises.

In addition to these large-scale mixed arable and dairy farms the clay soils provide possibilities for very intensive specialized nursery cultivation (seed production, bulbs) and vegetable cultivation. But sandy soils too have their specific possibilities (asparagus and tree cultivation).

In addition to primary production, the production of knowledge is also important. Well-educated farmers are able to carry out practical experiments in the interest of innovation in the chain. Knowledge is also exported within the organization of the enterprises themselves. More and more often these enterprises operate internationally, produce at many locations across Europe and train the personnel of the satellite companies at the headquarters in the Netherlands.

This way these enterprises export their own successes and cultivate their own competition. In combination with the high land prices the only long-term option for primary production in The Netherlands is competition via innovative capacity and quality in the broadest sense.

\section{'Dreams and folks stories'}

In the immediate vicinity of the metropolis, close to the cities and in areas where there is a great deal of recreational activity, there are real possibilities for the 'Arcadian reference' in the form of biological and regional products but also, for 
instance, farm camp sites and children's farms. These enterprises will become more professional and here too the initial stages of chain and network development can be observed. The link with food production will become more and more tenuous and eventually remain a mere functional part of the marketing of these enterprises.

\section{Management of nature and landscape}

The development of types of management for nature areas, separate from food production, has found inroads in The Netherlands via the so-called New Nature Areas. And although landscape management is applied on a large scale in agrarian nature management, innovations are also taking place here, offering possibilities for sustainable alternatives such as the development of new estates in rural areas with rights of way stipulated by the public authorities for the management of landscapes accessible to the public.

The greatest challenge, however, is elsewhere in Europe, away from the metropolitan areas. The former extensive animal-husbandry areas in the hill and mountain regions are at present being marginalized on a large scale. In these areas no European subsidies will be able to retain the extensive agriculture and the nature areas will be allowed to regenerate themselves. That is not a question of simple laissez faire but a process that via area-specific reconstruction over several years must be carried out (Rabbinge, Van Latesteijn and Smeets 1996).

\section{Knowledge, innovation and technology}

A virtual network linked to all the four above-mentioned perspectives can make the development of knowledge play a key role. Knowledge is even seen as the most beneficial long-term product in terms of revenue for the food-production sector, the 'Arcadian reference' and the development of new types of management for nature areas and landscape. But without practical application the development of this knowledge will rapidly stagnate in The Netherlands. The innovations driving these developments originate from practical applications and are market-oriented (Verkaik 1997). And these practices comprise, as hopefully has been demonstrated above, not only enterprises but what is indicated in the 'The Initiation of System Innovations' (Vasbinder and Groen 2000) as the combination of knowledge institutions, public authorities, social organizations, the population and enterprises which together develop and innovate food production, the management of nature areas and the landscape, and the 'dreams and folk stories' in their specific spatial configurations.

\section{And the farmer.......}

There is a sixth perspective in agriculture and spatial planning that must be mentioned here. That is traditional agriculture that, heavily addicted to export subsidies, tariff walls, price-support measures, income premiums and everything that Brussels has come up with in recent years, will do anything to continue these subsidies. In all, the subsidies on average account for half of the farmer's income. It is therefore worth the farmer's trouble to spend at least half his time trying to maintain them. The resultant lobby appears to be extremely persistent and effective. The subsidies work like hard drugs: very addictive and hardly mind-expanding, they block the development of the innovations described above. The following quote from the Polish minister of Agriculture in The Economist (The angry farmers 2002), in an article about the blockades thrown up by discussion about the Common Agricultural Policy in the context of accession of the central and Eastern European countries to the European Union, is very appropriate in this context: "Why don't we just scrap all the 
subsidies, and compete on a level playing field?" "If only", adds The Economist meaningfully.

\section{References}

The angry farmers, 2002. The Economist, 362 (8259), 25-26.

De Wilt, J.G., Van Oosten, H.J. and Sterrenberg, L., 2000. Agroproductieparken, perspectieven en dilemma's. Innovatiewerk Groene Ruimte en Agrocluster, Den Haag.

Europese Commissie, 1995. Europa 2000+: samenwerking voor de ruimtelijke ordening van Europa. Bureau voor Officiele Publikaties der Europese Gemeenschappen, Luxemburg.

Hoeren tussen de boeren, 2000. Binder: Nederlands Agrarisch Jongeren Contact, 19 (6), 4-5.

Ingram, G.K., 1997. Patterns of metropolitan development: what have we learned?

World Bank, Washington DC.

[http://www.worldbank.org/html/dec/Publications/Workpapers/WPS1800serie s/wps1841/wps1841.pdf]

Langelaan, I.S. and De Bont, C.J.A.M., 1999. Ontwikkeling van land- en tuinbouw in Nederland: verkenning van de situatie in 2010. In: In de verandering ligt de versterking: orientatie op de toekomst van agrarische bedrijven en hun behoefte aan dienstverlening en belangenbehartiging. LTO-Nederland, Den Haag.

McNeill, W.H., 1987. The eccentricity of wheels, or Eurasian transportation in historical perspective. American Historical Review, 92 (5), 1111-1126.

Ministerie van Landbouw, Natuurbeheer en Visserij, 2002. Structuurschema Groene Ruimte 2: samen werken aan groen Nederland. Ministerie van Landbouw, Natuurbeheer en Visserij, Den Haag. [http://www.minlnv.nl/thema/groen/ruimte/sgr2/]

Ministerie van Volkshuisvesting, Ruimtelijke Ordening en Milieubeheer, 2001. Ruimte maken, ruimte delen: vijfde nota over de ruimtelijke ordening 2000/2020. Ministerie van Volkshuisvesting, Ruimtelijke Ordening en Milieubeheer,Centrale Directie Communicatie, Den Haag.

Netherlands Scientific Council for Government Policy, 1992. Ground for choices: four perspectives for the rural areas in the European Community. SDU, The Hague. Reports to the Government no. 42.

Rabbinge, R., Van Latesteijn, H.C. and Smeets, P.J.A.M., 1996. Planning consequences of long term land-use scenario's in the European Union. In: Jongman, R.H.G. ed. Ecological and landscape consequences of land use change in Europe. European Centre for Nature Conservation ECNC, Tilburg. ECNC Publication Series on Man and Nature no. 2.

Smeets, P.J.A.M., 1998. Neurocity of deltametropool? Stedebouw en Ruimtelijke Ordening, 79 (2), 10-13.

Turn up the lights, a survey of cities, 1995. The Economist, 336 (7925).

Tweede Benelux structuurschets = deuxième esquisse de structure Benelux, 1996. Brussels, Secretariaat Generaal Benelux Economische Unie.

Van Broekhuizen, R., Klep, L., Oostindië, H., et al. (eds.), 1997. Atlas van het vernieuwend platteland. Misset, Doetinchem.

Vasbinder, J.W. and Groen, T., 2000. Initiëren van systeeminnovaties. Innovatiewerk Groene Ruimte en Agrocluster, Den Haag. 
Verkaik, A.P., 1997. Uitdagingen en concepten voor toekomstig landbouwkennisbeleid. Nationale Raad voor Landbouwkundig Onderzoek, Den Haag. NRLO-rapport no. 97/17.

Wallerstein, I., 1980. The modern world system. II. Mercantilism and the consolidation of the European world-economy. Academic Press, New York. 